DEPÓSITO LEGAL ZU2020000153

Esta publicación científica en formato digital

es continuidad de la revista impresa

ISSN 0041-8811

E-ISSN 2665-0428

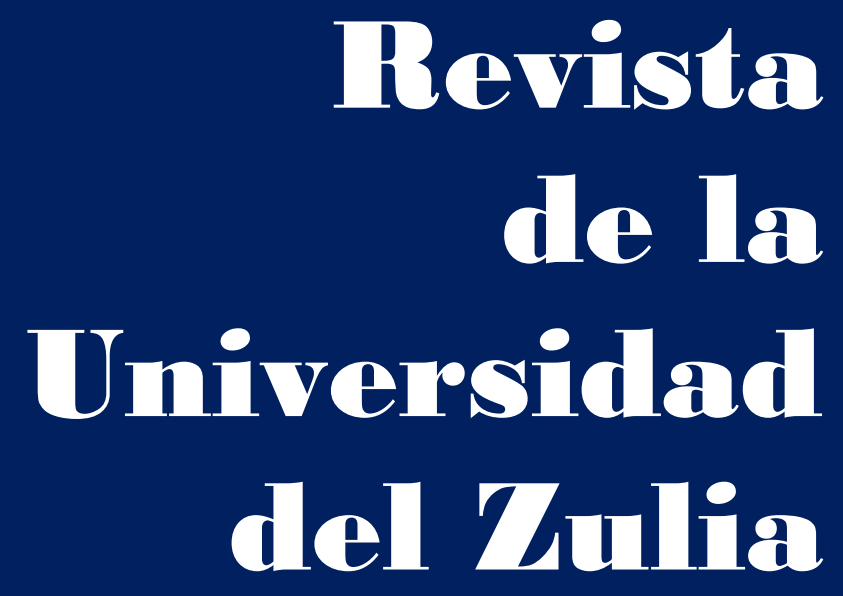

Fundada en 1947

por el Dr. Jesús Emrique Lossada

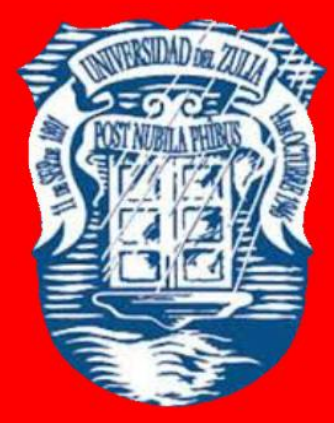

Ciencias

Sociales

y Arte

Año $12 \quad N^{\circ} 34$

Septiembre - Diciembre 2021

Tercera Época

Maracaibo-Veneruela 


\title{
The concept of constitutional pluralism as the fundamental basis for the development of the European Union legal order
}

\author{
Vitalii Gutnyk * \\ Ivan Bratsuk ** \\ Stepan Burak *** \\ Antonina Zubareva ****
}

ABSTRACT

The objective of this article is to analyze the concept of constitutional pluralism as a methodological basis for the construction of the legal system of the European Union. In particular, attention is paid to investigating the particularities of the interaction and operation of the different constitutional legal systems within the legal sphere of the European Union, studying the constitutional collisions derived from the interaction of European Union law and the law national of the Member States. Dialectical, comparative legal, historical, systemic-structural and formal dogmatic methods were used in the research. The article concluded that the national constitutional courts of the Member States of the European Union can give priority to their constitutional rules only if those rules are clear and reflect substantial constitutional obligations. However, in any case, in order to maintain the coherence of the legislation of the European Union and the national legislation of the Member States, it is necessary to amend the national Constitutions of the Member States of the European Union.

KEYWORDS: European Union; law; pluralism; doctrines; courts.

* Doctor of legal sciences, professor of International Law Department, Ivan Franko National University of Lviv, Ukraine. ORCID: https://orcid.org/0000-0003-1401-4393. E-mail: vitalik_gutnik@ukr.net

** Candidate of legal sciences, associate professor of European Law Department, Ivan Franko National University of Lviv, Ukraine. ORCID: https://orcid.org/0000-0003-0164-7407

${ }^{* * *}$ Assistant of professor of European Law Department, Ivan Franko National University of Lviv, Ukraine. ORCID: https://orcid.org/0000-0002-5184-0451

${ }^{* * * *}$ Candidate of legal sciences, associate professor of International Law Department, Ivan Franko National University of Lviv, Ukraine. ORCID: https:/orcid.org/0000-0003-3994-2698 


\section{El concepto de pluralismo constitucional como base fundamental para el desarrollo del orden jurídico de la Unión Europea}

RESUMEN

El objetivo de este artículo es analizar el concepto de pluralismo constitucional como base metodológica para la construcción del ordenamiento jurídico de la Unión Europea. En particular, se presta atención a la investigación de las particularidades de la interacción y el funcionamiento de los diferentes ordenamientos jurídicos constitucionales dentro del ámbito jurídico de la Unión Europea, estudiando las colisiones constitucionales derivadas de la interacción del derecho de la Unión Europea y el derecho nacional de los Estados miembros. En la investigación se utilizaron métodos dialécticos, jurídicos comparados, históricos, sistémicos-estructurales y dogmáticos formales. En el artículo se llegó a la conclusión de que los tribunales constitucionales nacionales de los Estados miembros de la Unión Europea pueden dar prioridad a sus normas constitucionales sólo si dichas normas son claras y reflejan obligaciones constitucionales sustanciales. Sin embargo, en cualquier caso, para mantener la coherencia de la legislación de la Unión Europea y la legislación nacional de los Estados miembros, es necesario modificar las Constituciones nacionales de los Estados miembros de la Unión Europea.

PALABRAS CLAVE: Unión Europea; derecho; pluralismo; doctrinas; tribunales.

\section{Introduction}

The active development of integration processes taking place within the European Union (hereinafter - the EU) leads to further convergence and closer interaction of national legal systems of member states, which expands the range of legal relations governed by the EU law. At the present stage of development of legal science, legal doctrines are becoming increasingly important, thanks to which it is possible to effectively solve various problems, which sometimes cannot be answered within the traditional approaches and concepts of international and national law (Gogin et al, 2021). These processes are inherent in the law of the EU, which primarily due to its specific nature, in fact, challenged traditional approaches to understanding the idea of law, its legal nature and content. The concept of constitutional pluralism is new means by which the specifics of interaction and functioning of various constitutional legal systems within the EU at the supranational level and the national level are studied, as 
well as various conflicts arising from this interaction are eliminated. A key element is the constitutional courts of the EU member states, which must always ensure a balance within the EU's pluralistic legal order. Thanks to this concept, the directions of further development of both the law of the EU and the national law of the EU member states are delineated.

This article is devoted to analyzing of the concept of constitutional pluralism as a fundamental basis for the development of the EU legal order. Despite the importance of the study of constitutional pluralism in the EU law, the existing scientific research is limited only to some aspects of the subject of this paper.

In this article were solved the following tasks:

- to define the doctrinal approaches to the content of the concept of constitutional pluralism of the EU law;

- to formulate the main internal sources of the concept of pluralism in the EU law;

- $\quad$ to find out the specific features of the concept of pluralism through the prism of the relationship between the EU law and the national law of the Member States;

- to characterize the influence of the Federal Constitutional Court of Germany on the development of the concept of constitutional pluralism in the EU law;

The study was conducted through the critical analysis of the EU legal doctrine, the EU legislation, and the EU member states' legislation. Particular attention is paid to the practice of the Federal Constitutional Court of Germany.

The subjects of the research were norms of the EU law as well as the EU member states' legislation and practice of national courts. The subject study is the concept of constitutional pluralism.

\section{Literature review}

The concept of constitutional pluralism is reflected in the works of scholars such as N. MacCormick, G. Shaffer, R. Kwiecien, Jessica C. Lawrence, M. Wilkinson, N. Walker, J. Weiler, K. Ziegler, M. Maduro, M. Krisch, M. Kumm etc. For example, Jessica C. Lawrence - considers the concept of constitutional pluralism as a kind of discussion technique that solves the relationship between the legal orders (Lawrence, 2019). N. MacCormick considered this concept through the prism of the existence in the legal system 
of the EU law autonomous constitutional legal orders within each of them there is a legal field that interacts with each other (MacCormick, 1999). It seems interesting to approach M. Wilkinson, who understands this theory as one that characterizes the development of post-sovereign European state, and the author emphasizes that in the EU there is a multilevel constitutional structure formed by voluntary limited sovereignty by members of the EU (Wilkinson, 2019). N. Krisch considers this concept through the prism of the activity of national (constitutional) courts of the member states on the interpretation and application of the EU law because depending on effectively determining which rules to apply in settlement of disputes and how to establish interaction between different levels of government (supranational and national) will express constitutional pluralism (Krisch, 2013). Also interesting is the point of view of M. Avbelj who sees the observance of EU values as the goal of constitutional pluralism, and when an EU member state in the person of its constitutional courts makes decisions that are contrary to the basic values of the EU law, then these actions are by no means should be equated with constitutional pluralism (Avbelj, 2016).

\section{Methodology}

In the article were used dialectical, comparative legal, historical, system-structural and formal dogmatic methods.

The dialectical method gave the opportunity to consider the concept of constitutional pluralism in relation to other legal concepts. The comparative legal method was used to compare the understanding of the concept of constitutional pluralism in different decisions of the Federal Constitutional Court of Germany. The historical method is used to analyze the genesis of the concept of constitutional pluralism. The systemstructural method made it possible to consider constitutional pluralism as the complex concept in the law of the European Union. The formal-dogmatic method was used to interpret the provisions contained in the decisions of the Federal Constitutional Court of Germany.

3. Doctrinal approaches to the content of the concept of constitutional pluralism of the EU law 
Examining the content of legal pluralism in general, we can find the view that this concept should be considered through the prism of the possibility of coexistence of different potentially conflicting legal norms within one legal system. Moreover, these norms will not be mutually exclusive and will, if necessary, be selectively applied due to the legal mechanisms of the legal system. It is due to legal pluralism that the existing conflict between legal norms can be overcome, which is expressed and enshrined in legal acts of different legal forces (Jansen, 2012). At the same time, until recently, when the scope of international law was expanded by multilateral international treaties, legal pluralism was viewed solely through the prism of a clear division of monistic national legal orders and general, but limited in regulatory plan international law, which usually did not intersect. Thus, in this case, the emphasis is on integrative processes, as fundamental accumulating factors due to which legal pluralism is actively developing and changing. This concept essentially brings together different areas of law within the legal system. In this context, the point of view is actual that "constitutionalism and pluralism are distinguished ... by the different extent to which [each] formally link[s] the various spheres of law and politics. While pluralism regards them as separate in their foundations, global constitutionalism, properly understood, is a monist conception that integrates those spheres into one" (Shaffer, 2012).

One of the founders of the concept of constitutional pluralism is N. MacCormick who, studying the functioning of the EU legal system, came to the conclusion that this theory should be understood as "idea that two autonomous legal and political systems can interact at a high degree of intensity, making simultaneous claims to ultimate authority, without one being ubordinated to the other. But conflicts between two systems interacting in this wayshould be resolved according to prudential judicial politics,or principles, shared by, orexternal to, both systems" (MacCormick, 1999). Examining this question, the scholar admits the possibility of the existence within one EU legal system of multiple legal orders, each of which together with its current constitution is legitimate and operates within its own sphere and whose main purpose is to prevent the constitutional supremacy of one legal order over others.

The concept of constitutional pluralism has acquired specific features in EU law and has become not only a tool for resolving "conflict" situations in EU law, but also an effective 
means of understanding the unique legal nature of EU law as a whole. For example, R. Kwiecien concludes that from the standpoint of material sources of law, the legal order of the EU and the national (constitutional) legal orders of the Member States are complementary sets of legal norms and values, which are expressed and embodied in them. Therefore, such a relationship can be called "constitutional pluralism", "European legal pluralism", "multi-center legal system" or "European unwritten social contract", which will result in the coordination of legal systems (Kwiecien, 2005). Thus, given to cosideration the growing convergence of the legal systems of the EU Member States, the relationship between EU supranational law and the national constitutional law of the Member States is often defined by various concepts, but in general the term pluralism best reflects this interaction.

In this context, we share the point of view of Jessica C. Lawrence according to which,

"constitutional pluralism marks certain conflicts as legitimate despite their lack of a single source of 'legality'. It does this by shifting the legitimating function to some other norm-whether cosmopolitan values, fundamental rights, shared conflict resolution principles, an alternative constitutional order, or something else" (Lawrence, 2019).

Considering this concept, it should be noted that among scientists there are different approaches to its understanding and scope. Thus M. Wilkinson understands it as a theory that is applied and characterizes development of the post-sovereign European state and state-system. He emphasizes that the key role in this theory is played by two aspects: "first, the concept of sovereignty-understood as ultimate political authority-is folded into constitutional authority, into the constitution itself, and thereby into its authoritative interpreters, particularly, if not exclusively, constitutional courts"; "second, constitutional authority is then presented as quasi-federal or compound in nature, a feature of a multilayered constitutional system comprising the domestic constitution and a European constitution (and their respective authoritative interpreters)" (Wilkinson, 2019). According to the scientist, there is a multilevel constitutional structure in the EU, which was formed due to the voluntary limited sovereignty of the EU member states, and which is actively functioning and changing. 
Other scholars use the term "multilevel constitutionalism" to mean the coexistence of different constitutional bodies within a broader system of government, none of which ultimately has supremacy, as well as a strict regime of competence that preserves the autonomy of the respective spheres. In other words, the legal and constitutional systems of the EU are parallel, in the sense that they coexist in a more or less horizontal or "hierarchical" relationship (Walker, 2002). At the same time, they are intertwined, but each of them has its own independent legal and constitutional zone outside the sphere of overlap.

At the same time, it should be noted that the Lisbon Treaty is also not a form of "supreme law", which is endowed with higher legal force in relation to national constitutions, they rather coexist in parallel planes. However, in this context, the position of a number of authors is interesting, who believe that the amount of freedom of action of the EU due to the Lisbon Treaty has increased so much that in some policy areas the European Union has a form typical of federal states. Whereas internal decision-making and the appointment of procedures correspond to the structure of an international organization (Kellenberger, 2003; Weiler, 2001). EU law already has supreme legal force because it has supremacy over any contradictory rules of national law, but this form of supremacy is only pragmatic.

J. Weiler shares this position and views the EU legal order through the prism of European integration, which already exists as a constitutional unity and does not need a new constitution, which would be enshrined in the traditional constitutional way, because it (integration) meets this purpose (Weiler, 1996). This constitutional unity of the EU is based on the key principles established by the European Court of Justice for the relationship between EU law and national law (direct action and the rule of law). In this case, $\mathrm{K}$. Ziegler notes that constitutionalism in the dimension between the EU and its member states is characterized primarily by supranational rule-making of the Court of Justice through the prism of its mandatory jurisdiction and respect for rights and freedoms both in the international court and through direct action its decisions in the national courts of the Member States (Ziegler, 2013). Thus, EU constitutionalism is the normative legitimacy of the EU legal order, which ensures its legitimacy and is the driving force in its development (Avbelj, 2008). 
Quite interesting is the position of M. Maduro, who states that:

"We can identify four main sources of internal pluralism. First, there is a plurality of constitutional sources (both European and national) which have fed the EU constitutional framework and its general principles of law, particularly as developed in the jurisprudence ofthe Court of Justice. Second, the acceptance of the supremacy of EU rules over national constitutional rules has not been unconditional, if not even, at times, resisted by national constitutional courts. This confers to EU law a kind of contested or negotiated normative authority. Third, there is an emergence of new forms of power that challenges the traditional private/public distinction and the different mechanisms of accountability associated to them. Such pluralism in the forms of power challenges, in turn, the traditional legal categories upon which EU rules have been framed. Fourth, the European Union is also dominated by a form of political pluralism that can assume a rather radical form since the conflicting political claims are often supported by corresponding claims of polity authority" (Maduro, 2007).

In general, the author takes the view that the main purpose of constitutional pluralism is to guarantee the integrity and coherence of the EU legal order. At the same time, he identifies certain mandatory requirements set by constitutional pluralism to achieve the above goal.

"The first, requirement of EU constitutional pluralism is that 'any legal order (national or European) must respect the identityof the other legal orders', in particular via the 'recognition and adjustment of each legal order to the plurality of equally legitimate claims of authority made by the other legal orders'. The second requirement is that discourse among constitutional actors must 'take place in such a way as to promote the broadest participation possible'. Third, the various actors in the European system must 'share the same commitment to a coherent legal order', adjusting their claims to authority in order to ensure consistency andvertical and horizontal coherence. Fourth, national courts ought to justify their decisions on 'universalisable' grounds that 'could be applied by any other national court in similar situations'. Fifth and finally, the principle of 'institutional choice' requiresthatconstitutional pluralism reject a singular focus on courts and judgments, and instead recognize the actions of a broader range of constitutional actors. So long as these requirements are fulfilled, it will remain 'possible to have a coherent legal order in acontext of competing determinations of the law' - conflicts over the ultimate locus of jurisdictional authority need not be resolved" (Maduro, 2003).

It should also be noted that the concept of constitutional pluralism in the EU was formed primarily in response to a number of cases in which the national constitutional courts of EU member states sought to determine whether EU law is compatible with a 
country's national constitutional order. At the same time, there have often been attempts to make decisions that would call into question the automatic rule of EU law, thereby challenging its primacy. Thus, the constitutional courts of the EU Member States have questioned the rule of European Union law over national constitutional norms, on the grounds that they are the guarantee of national human rights standards and democratic principles. In this activity, how effectively they will determine which norms (EU law or national constitutional provisions) to apply in resolving a dispute and how to establish the interaction of different levels of government (supranational and national) and will express constitutional pluralism. In this case, we share the view that,

"we will find properly "constitutional" pluralism when rights are at issue and when rights-protecting courts (especially European ones) are the main actors. This does indeed fit most cases typically seen as expressions of pluralism in action, and it is plausible even if one does not think that pluralism is all about rights. Court action is often triggered by rights claims, and unlike most other political actors, courts need to give a principled account of what they do, so they need to clarify the relation of different levels of authority. It is through this clarification-and the conflicting accounts of different courts-that we can best gauge the presence of a pluralist order" (Krisch, 2013).

Quite interesting is the point of view of M. Kumm, who proves the importance of pluralism, exploring the features and specifics of the relationship between the EU and national law of the Member States (Kumm, 1999). In particular, examining the development of pluralism in the EU legal order, the author identifies two possible trends in its development. The first is that constitutional courts will be able to repeal EU law on the basis of their specific constitutional norms and principles. According to another trend, Member States will very rarely be able to disregard EU law and do so only for positive reasons. The author is of the opinion that the second scenario is more plausible and constructive, and it is thanks to it that the effective interaction of EU law and national law of the Member States will take place over a long period of time. In this case, national courts will act as a driving, constructive force that will operate within the EU legal order and whose main goal will be to increase the level of democracy in the decision-making process at the level of the European Union.

It is national courts that will give the Court of Justice of EU an incentive to pay more attention to issues of legislative jurisdiction and to be more careful in analyzing its 
REVISTA DE LA UNIVERSIDAD DEL ZULIA. 3e época. Año $12 \mathrm{~N}^{\circ}$ 34, 2021

Vitalii Gutnyk et al. /// The concept of constitutional pluralism as the fundamental basis... 361-378 DOI: http://dx.doi.org/10.46925//rdluz.34.21

fundamental rights (Kumm, 2005). It should be noted, however, that national constitutional courts are likely to give priority to their constitutional provisions only if such provisions are clear and genuinely specific and reflect their essential constitutional obligations. However, in any case, in order to maintain the coherence of EU law and the national law of the Member States, it is necessary to amend the national constitutions or to ensure the withdrawal of such Member States from the EU if they refuse to do so.

However, it should be noted that the key role in this case will be played by how the basic postulates of this theory are implemented in practice, in the context of the decision of the national constitutional courts of the Member States in the spirit of constitutional pluralism. Because they may often be tempted to make a decision that would contradict not only the basic principles of this theory but also EU law as a whole. Therefore, it is worth supporting the view that "pluralist insistence on the respect for national constitutional autonomy, for the national pluralist-self, cannot be misused or even abused to legitimate national measures corrosive of the EU fundamental values under the guise of pluralism" (Avbelj, 2016). In other words, when an EU Member State, represented by its constitutional courts, makes decisions that are contrary to the fundamental values of the EU law, then these actions should in no way be equated with constitutional pluralism. In this context, we fully share the point of view of Jessica C. Lawrence who examining the normative content of constitutional pluralism in the EU concludes that

"its normative content is far more determinate than it appears: it is not only a commitment to an 'ever closer union' or 'democratic values' or 'respect for diversity' or any other abstract concept that makes behavior an acceptable instance of constitutional pluralism - it is also necessary to be a 'normal', 'well-ordered' (Western) European state that acts within acceptable bounds. These values may be historically, geographically, and politically contingent, may shift over time, and may not be applied with equal fervor to all actors in the system, but they are most certainly present" (Lawrence, 2019).

4. The influence of the Federal Constitutional Court of Germany on the development of the concept of constitutional pluralism in EU law

Among the decisions of the Constitutional Courts of the EU member states, the most important for analysis are the decisions of the Federal Constitutional Court (FCC) 
of Germany, which in some cases were ambiguous and sometimes not fully fit into the concept of constitutional pluralism. First of all, the FCC tried to retain the power to review EU law regarding its compatibility with fundamental rights and with the division of powers between the European and national levels of government. A clear example of this position was the case of Solange I, in which the Court took a principled position on the application of "secondary" EU law in accordance with fundamental human rights in Germany (Diete, 1998). The Federal Constitutional Court of Germany, recognizing the exclusive right of the Court of Justice to decide on the validity and interpretation of EU law, noted that the Court of Justice of the EU cannot rule if existing EU law is incompatible with the national Constitution. The FCC has the exclusive competence to decide that a norm of EU law (if it violates the Constitution) cannot be applied by the courts. And the effect of "secondary" EU law in the Federal Republic is subject to review by the Federal Constitutional Court, in addition to any review of fundamental rights by the Court of Justice of the EU. This practice will be applied "until the integration process reaches the adoption in EU law of the list of fundamental rights adopted by the parliament, which will correspond to the list of fundamental rights contained in the Constitution" (BVerfG decision: Internationale Handelsgesellschaft v. Einfuhr und Vorratsstelle für Getreide und Futtermittel, 1974).

Somewhat inconsistent with the first decision was the FCC's decision in Solange II, in which the court stated that it would no longer monitor the compatibility of Community law with Germany's fundamental rights, so in particular in this case the FCC emphasized that as long as the European Community, and in particular the Court of Justice, does not ensure effective protection of fundamental human rights under Community acts, which essentially provide for equal protection of fundamental rights in the German Constitution, the Federal Constitutional Court will not exercise jurisdiction and decide on the application of Community by-laws... and will no longer review such legislation in accordance with the fundamental rights standards enshrined in the Constitution, nor can an action be brought before a court for that purpose (BVerfG decision: Solange II, 1986). In addition, the Court held that such a decision had been reached on the belief in fundamental rights, in particular those protected by the European Court of Justice. Thus, it seems that the FCC has finally recognized the 
protection of fundamental rights at Community level as sufficient, and theoretically remains interested in asserting its claims for due process, thus recognizing the doctrine of the rule of EU law, including over German constitutional norms. This decision meant, on the one hand, the rejection of the position enshrined in the Solange I and, on the other hand, reaffirmed the Constitutional Court's requirement that the German Constitution be superior to EU law, thereby strengthening the court's authority to consider the compatibility of the EU law and the German Constitution, especially in cases of serious violations of fundamental human rights (Winkelmann, 1994).

Another important case, which examined the constitutional relationship between EU law and German law, was the Maastricht case, which challenged the constitutionality of state ratification of the EU Treaty. After considering the case, the FCC noted that ratification was compatible with the Constitution. However, it was stressed that the FCC would continue to consider the issue of compliance of EU law with the norms of the Constitution of Germany. Also in this case, the FCC raised a number of legal issues related to the binding force and applicability of EU law in Germany. In particular, the court argued that the Member States still remain so-called "owners of agreements" (Herren der Verträge) and that the binding force of EU law depends primarily on German national law. Thus, the EU does not have the power to decide where the limits of EU power end and to determine its own competence. The Court also stated that it would apply its jurisdiction to implement the rules of "secondary" EU law, and thus verify their compliance with fundamental rights regarding "cooperation" with the European Court of Justice (BVerfG decision: In Re Maastricht Treaty, 1993). In other words, the Court noted that the force of EU law in Germany follows from the provisions of the German Constitution, which approved the delegation of powers to international organizations. It was also criticized the extension of the EU's competence through mechanisms such as flexibility, noting that if the competence were expanded, it could cease to be legally binding in Germany. In this case, it can be concluded that the German FCC intended to fully restore its judicial review, which it refused on the basis of the Solange II decision, which once again confirms how difficult and important was the issue of recognizing the supremacy of EU law over the Constitution in Germany. Consequently, in the present case, the Constitutional Court again departed from the 
provisions of the Solange II decision, stating that permanent review of the jurisdiction of the court was imposed due to the lack of a specific mechanism for the protection of fundamental human rights within the Community (Horn, 1995). After this decision, it became clear that the German court and the Court of Justice of the EU took different positions on the understanding of the relationship between European and national legal systems. Their main differences also presented the possibility of legal confrontation, which could give rise to a European constitutional crisis.

In its next case, the Bananenmarktordnung, the FCC reaffirmed only its power to review EU law only in certain, defined circumstances, both procedurally and in substance. The Court reaffirmed its right to limited, conditional control over the procedure of a legal issue and a constitutional complaint concerning EU law and found that it could not determine the compatibility of EU provisions and fundamental rights enshrined in the German Constitution. For this reason, any proposal for constitutionality should be rejected as unacceptable if it lacks a justification for lowering the standard of protection of human rights (especially in the case-law of the Court of Justice of the EU) in relation to the required level of protection (BVerfG decision: Bananenmarktordnung, 2000). In other words, the FCC does not have general jurisdiction over secondary law in the context of German fundamental rights, because the protection of rights is carried out at the Union level.

Finally, in the case of the Bundesverfassungsgericht, the FCC assessed the compliance of the Lisbon Treaty with the provisions of the German Constitution and concluded that it had no grounds for disapproving of the Lisbon Treaty. However, the FCC proposed certain restrictions on Germany's future integration by committing itself to clearly define the basic powers of the state, which cannot (or only under exceptional conditions) be transferred to the European Union and must always be at the national level. In particular, it was noted that there should always be "a guarantee that excludes the transfer of the identity of the constitutional order of Germany, even in the context of restrictions on the revision of the Constitution by the legislature at the supranational level, which in turn guarantees the sovereign status of the state". The Constitution requires that nation-states remain the owners of treaties at all times. In functional terms, the source of power in the EU is the people of Europe with the democratic 
constitutions of their states. The supranationality of the EU will develop rapidly in the political aspect, but it will always be limited (BVerfG decision: Bundesverfassungsgericht, 2009).

Analyzing this decision of the FCC, we share the view of A. Steinbach that the decision of the FCC on the Lisbon Treaty provides a clearer form of the category of "important areas of responsibility" that states must retain. The reason for this concretization is the reaction to the constant expansion of the EU's powers and the need to define sufficient space for the political formation of economic, cultural and social living conditions by member states, which should not disappear in the member states due to European unification based on the union sovereign states. This applies to areas that shape the living conditions of citizens, especially private space, their own responsibility and political and social security protected by fundamental rights, as well as political decisions that are particularly dependent on prior understanding of culture, history and language (Steinbach, 2010). The gradual and growing transfer of national powers to EU bodies forced the FCC to outline for the first time in this decision those basic state powers that cannot be transferred to the EU. However, the criteria used by the FCC to single them out cannot claim to be universal in forming a set of inalienable sovereign rights throughout the European Union. For example, due to cultural diversity, multilingualism is not seen in other EU member states as an obstacle to the functioning of their legal order.

Hence, it can be concluded that the German Constitutional Court has for a long time tried to preserve the right to constitutional review of EU legal acts on their constitutionality, which in turn manifested itself in a number of decisions we analyzed above. However, it should be noted that no EU norm was declared optional and not applicable in Germany on the basis of ultra vires, during such a constitutional review by the Constitutional Court of Germany. Thus, the FCC never risked creating an open conflict with the European Union and the Court of Justice, which in general fully corresponds to the concept of constitutional pluralism. There is close cooperation between the constitutional courts and the European Court, which is based on the principles of mutual respect and the guarantee of national identity. At the same time, this cooperation, which is expressed in close dialogue and interaction between the 
Court of Justice and the national courts of the Member States, essentially contributes to the development of a pluralistic European legal order as a whole (Pollicino, 2010).

In general, constitutional pluralism is a theory that was created to clarify the issue of the hidden confrontation between EU law and the national (constitutional) law of the member states. Following the adoption of the Lisbon Treaty, the EU legal order can be described as constitutional pluralism, in which the legal systems of the EU and the Member States define parallel and overlapping areas. In this context, the position of some authors is noteworthy, who note that the reorganization of the Treaty establishing a Constitution for Europe (TCE) into the Lisbon Treaty is a transition from one way of understanding these relations - constitutional federalism, to another - constitutional pluralism (Avbelj, 2008; Cruz, 2008). Thus, the legal order in the EU after the entry into force of the Lisbon Treaty is very close to the principles of constitutional pluralism. M. Claes notes that most parts of the Constitutional Treaty have been selected and found their place in the Lisbon Treaty. But to say that there are no changes at all is like saying that the pieces of a broken vase, if glued together, will have a preliminary appearance. The difference, however, is not just between the two vases. In addition, the fact that the vase was first broken and then glued together is reminiscent of this event (Claes, 2008).

\section{Conclusions}

Thus, the content of constitutional pluralism as a concept of the functioning of the EU legal order, which was formed to resolve the issue of hidden confrontation between EU law and national (constitutional) law of member states is that the phenomenon of multiple constitutional sources that creating the conditions for potential constitutional conflicts between different legal systems need to be decided only in conditions of equality. At the same time, the EU legal order is viewed through the prism of European integration, which already exists as a constitutional unity and does not need a new constitution, which would be enshrined in the traditional constitutional way. This constitutional unity of the EU is based on the principles established by the Court of Justice of the EU for the relationship between EU law and the national law of the Member States (direct action and the rule of EU law).

According to this concept, the national constitutional courts of the EU Member States can give priority to their constitutional norms only if such norms are clear and 
REVISTA DE LA UNIVERSIDAD DEL ZULIA. $3^{a}$ época. Año $12 \mathrm{~N}^{\circ}$ 34, 2021 Vitalii Gutnyk et al. /// The concept of constitutional pluralism as the fundamental basis... 361-378 DOI: http://dx.doi.org/10.46925//rdluz.34.21

reflect substantial constitutional obligations. However, in any case, in order to maintain the coherence of EU law and the national law of the Member States, it is necessary to amend the national constitutions of the EU Member States. And although the Constitutional Courts are competent to exercise de facto some control over the rules of EU law, because otherwise the national constitutional norms will be in danger of disappearing and being completely replaced by the rules of EU law. However, they are obliged to interpret domestic law as close as possible to EU law, and in case of conflicts to terminate certain national constitutional norms.

\section{References}

Avbelj, M. (2016). Pluralism and Systemic Defiance in the EU. In: A. Jakab and D. Kochenov (eds). The Enforcement of EU Law and Values. Oxford: Oxford University Press. DOI:10.1093/acprof:oso/9780198746560.003.0004

Avbelj, M. \& Komarek, J. (2008). Four Visions of Constitutional Pluralism. Symposium Transcript. European Journal of Legal Studies, 2 (1), 325-370.

Avbelj, M. (2008). Questioning EU Constitutionalisms. German Law Journal, 9 (1), 1-26. Retrieved from: https://ssrn.com/abstract=1113498

BVerfG decision: Bananenmarktordnung. (2000). Retrieved from: https:/www.bundesverfassungsgericht.de/SharedDocs/Entscheidungen/EN/2000/06/ls200 00607_2bvl000197en.html

BVerfG decision: Bundesverfassungsgericht. (2009). Retrieved from: https:/www.bundesverfassungsgericht.de/SharedDocs/Entscheidungen/EN/2009/06/es200 90630_2bve000208en.html

BVerfG decision: Internationale Handelsgesellschaft v. Einfuhr und Vorratsstelle für Getreide und Futtermittel. (1974). Retrieved from: https:/eur-lex.europa.eu/legalcontent/DE/TXT/PDF/?uri=CELEX:61970CJ0011\&from=EN

BVerfG decision: In Re Maastricht Treaty (1993). Retrieved from: https://iow.eui.eu/wpcontent/uploads/sites/18/2013/04/06-Von-Bogdandy-German-Federal-Constitutional-

Court.pdf

BVerfG decision: Solange II (1986). Retrieved from: https://aw.utexas.edu/transnational/foreign-law-translations/german/case.php?id=572

Claes, M. \& Eijsbouts, W.T. (2008). The Difference. European Constitutional Law Review, 4 (1), 1-19. DOI: https://doi.org/10.1017/S1574019608000011 
REVISTA DE LA UNIVERSIDAD DEL ZULIA. $3^{a}$ época. Año $12 \mathrm{~N}^{\circ}$ 34, 2021 Vitalii Gutnyk et al. /// The concept of constitutional pluralism as the fundamental basis... 361-378 DOI: http://dx.doi.org/10.46925//rdluz.34.21

Cruz, B.J. (2008). The Legacy of the Maastricht-Urteil and the Pluralist Movement. European Law Journal, 14 (4), 389-422. DOI: https://doi.org/10.11l1/j.1468-0386.2008.00419.x

Dieter H. S. (1998). Deutsches Verfassungsrecht und Europäische Integration, 157-207. In: P-C. Muller-Graff und E. Riedel (Hg.), Gemeinsames Verfassungsrecht in der Europäischen Union. Baden-Baden.

Gogin, A. A., Fedorova, A. N., Vagapov, R. F., \& Sergeev, A. V. (2021). Austrian and Russian constitutionalism: comprehensive analysis. Amazonia Investiga, 10(41), 121-130. https://doi.org/10.34069/AI/2021.41.05.12

Horn H.-D. (1995). Grundrechtsschutz in Deutschland - Die Hoheitsgewalt der Europäischen Gemeinschaften und die Grundrechte des Grundgesetzes nach dem Maastricht-Urteil des Bundesverfassungsgerichts. Deutsches Verwaltungsblatt DVBL, 89-96.

Lawrence, J.C. (2019). Constitutional Pluralism's Unspoken Normative Core. Cambridge Yearbook of European Legal Studies, 21, 24-40. DOI: https://doi.org/10.1017/cel.2019.12

Kellenberger J. (2003). Federalism in Foreign Relations, 189-194. In: R. Blindenbacher and A. Koller (eds.). Federalism in a Changing World: Learning from each other. McGill-Queen's University Press.

Krisch, N. (2013). Constitutionalism and pluralism: A reply to Alec Stone Sweet. International Journal of Constitutional Law, 11 (2), 501-505. DOI: https://doi.org/10.1093/icon/mot010

Kumm, M. (2005). The Jurisprudence of Constitutional Conflict: Constitutional Supremacy in Europe before and after the Constitutional Treaty. European Law Journal. 11(3), 291-292. DOI: https://doi.org/10.111l/j.1468-0386.2005.00260.x

Kumm, M. (1999). Who is the Final Arbiter of Constitutionality in Europe?: Three Conceptions of the Relationship between the German Federal Constitutional Court and the European Court of Justice. Common Market Law Review, 36, 35l-386. Retrieved from: https://kluwerlawonline.com/journalarticle/Common+Market+Law+Review/36.2/202713

Kwiecien, R. (2005). The Primacy of European Union Law Over National Law Under the Constitutional Treaty. German Law Journal, 6 (11). 1479-1495. DOI: https://doi.org/10.1007/978-3-540-37721-4_5

MacCormick, N. (1999). Questioning Sovereignty: Law, State, and Nation in the European Commonwealth. Oxford: Oxford University Press. DOI: https://doi.org/10.1093/acprof:oso/9780198268765.001.0001

Maduro, M.P. (2007). Interpreting European Law: Judicial Adjudication in a Context of Constitutional Pluralism. European Journal of Legal Studies, 1 (2), 1-21.

Maduro, M.P. (2003) Contrapunctual Law: Europe's Constitutional Pluralism in Action', 526-528. In: N. Walker (ed), Sovereignty in Transition. Oxford: Hart Publishing. 
REVISTA DE LA UNIVERSIDAD DEL ZULIA. 3e época. Año $12 \mathrm{~N}^{\circ}$ 34, 2021

Vitalii Gutnyk et al. /// The concept of constitutional pluralism as the fundamental basis... 361-378 DOI: http://dx.doi.org/10.46925//rdluz.34.21

Jansen, N. (2012). Legal Pluralism in Europe - National Laws, European Legislation, and Non-Legislative Codifications. Legal Pluralism. Retrieved from: https://papers.ssrn.com/sol3/papers.cfm?abstract_id=1840356

Pollicino, O. (2010). The New Relationship between National and the European Courts after the Enlargement of Europe: Towards a Unitary Theory of Jurisprudential Supranational Law? Yearbook of European Law, 29 (1), 65-11l. DOI: https://doi.org/10.1093/yel/29.1.65

Shaffer, G. (2012). A Transnational Take on Krisch's Pluralist Postnational Law. European Journal of International Law, 23 (2), 565-582, DOI: https://doi.org/10.1093/ejil/chs029

Steinbach, A. (2010). The Lisbon Judgment of the German Federal Constitutional Court New Guidance on the Limits of European Integration? German Law Journal, 11(4), 367-390. DOI:10.1017/S2071832200018587

Walker, N. (2002). The Idea of Constitutional Pluralism. The Modern Law Review, 65, 317359. DOI: https://doi.org/10.11l1/1468-2230.00383

Weiler, J. (2001). Federalism Without Constitutionalism: Europe's Sonderweg: 54-72. In: T. Kalypso Nicolaidis and Robert Howse. The Federal Vision: Legitimacy and Levels of Governance in the United Statse and the Europian Union, Oxford Universety Press.

Weiler, J. H. (1996). European neo-constitutionalism: in search of foundations for the European constitutional order. Political Studies, 44, 517-533. DOI: https://doi.org/10.11l1/j.1467-9248.1996.tb00598.x

Wilkinson, M. (2019). Beyond the Post-Sovereign State?: The Past, Present, and Future of Constitutional Pluralism. Cambridge Yearbook of European Legal Studies, 21, 6 - 23. DOI: https://doi.org/10.1017/cel.2019.9

Winkelmann I. (1994). Das Maastricht-Urteil des Bundesverfassungsgerichts. Vom 12. Oktober 1993. In: Winkelmann, Ingo (Hrsg.). Dokumentation der Verfahrens mit Einführung. Tübinger Schriften zum Staats- und Verwaltungsrecht Band 25. Berlin: Duncker \& Humblot.

Ziegler, K. (2013). International and EU law: between asymmetrical constitytionalization and fragmentation. Legal Journal "Law of Ukraine", 3, 5-12 